\title{
Motivation of Employees 50+
}

\author{
Danica Bakotić, PhD, \\ Srećko Goić, PhD, \\ Ivana Tadić, PhD,
}

University of Split, Faculty of Economics, Croatia

URL:http://dx.doi.org/10.19044/esj.2018.c5p4

\begin{abstract}
In recent years, employees older than 50 years of age represent a significant work force and companies have become aware of their importance. They have to be managed in a specific way by motivating and encouraging them in achieving extraordinary performance. However, in the literature, there is a lack of empirical research about older employees. Because of that, the aim of this paper is to explore the motivation of employees $50+$ This paper is based on the large empirical investigation conducted within the project InCounceling 50+ co-funded by the European Commission through the Erasmus+ Programme. The research in Croatia was conducted in 2017 in 6 Croatian companies. The research instrument was a specially designed questionnaire with 30 questions. The questions relevant for this paper were about employees' general characteristics, employees' competencies and motivational factors. These questions were completed by 141 employees. The collected data was analyzed by the usual statistics methods supported by SPSS program. The research results showed that employees 50+ consider that they have sufficient or even higher competencies required for their job position. Regarding motivational factors, good atmosphere at work is the most important motivational factor for employees 50+, followed by the respect and recognition and safety and stability of the employment. Career development is the least important motivational factor for employees 50+. Additionally, research results showed that there are no statistically significant differences in motivational factors of employees 50+ regarding their gender, educational level and job position.
\end{abstract}

Keywords: Motivation, theories of motivation, employees 50+

\section{Introduction}

In recent years, there has been an increase in the participation of people 50+ in working and social life. They represent a significant work 
force and companies have become aware of their importance. Those employees have to be managed in a specific way by motivating and encouraging them to achieve extraordinary performance. However, in the literature, there is a lack of empirical research about employees 50+. Therefore, the aim of this paper is to explore the motivation of employees $50+$. According to this, the research questions of this paper are:

(1) Do employees 50+ have enough developed competencies for their job positions?

(2) What are the motivational factors that employees $50+$ consider as important?

(3) Are there any differences in motivational factors related to gender, level of education or job position for employees $50+$ ?

This paper is organized in the following way. After the introduction, there is a theoretical overview that explores the definition of motivation and theories of motivation, as well as the motivation specifics of older adults. The third section provides information about research methodology. The fourth section presents research results. Concluding remarks are done in the final section. At the end of the paper, there is a list of references.

\section{Theoretical overview}

\section{Definition and theories of motivation}

Motivation is defined as forces within the individual that account for the direction, level, and persistence of a person's effort expended at work. Direction refers to an individual's choice when presented with a number of possible alternatives (e.g., whether to pursue quality, quantity, or both in one's work). Level refers to the amount of effort a person puts forth (e.g., to put forth a lot or very little). Persistence refers to the length of time a person sticks with a given action (e.g., to keep trying or to give up when something proves difficult to attain) (Schermerhorn et al., 2012). Several theories offer explanations of motivation. Most of them can be separated into two groups: content theories and process theories.

Content theories are based on the premise that humans are motivated primarily by deficiencies in one or more important needs or need categories. The important content theories are: Hierarchy of Needs Theoryand TwoFactor Theory.

\section{Hierarchy of Needs Theory}

One of the most popular motivation theories, frequently referred to as the hierarchy of needs theory, was proposed in the 1940s by Abraham Maslow. According to Maslow, people are motivated by their desire to satisfy specific needs. Maslow arranged these needs in hierarchical order, with physiological needs at the bottom, followed by safety needs, social and 
belongingness needs, esteem needs, and, at the top, self-actualization needs. In general, lower-level needs must be substantially met before higher-level needs become important.

1. Physiological needs include basic survival needs-for water, food, air, and shelter. Money is one organizational award that is potentially related to these needs, to the extent that it provides for food and shelter.

2. Safety needs include the need for protection from physical or psychological harm. People at this level might consider their jobs as security factors and as a way to keep what they have acquired.

3. Social needs involve interaction with and acceptance by other people. These needs include the desire for affection, affiliation, friendship, and love.

4. Esteem needs relate to feelings of self-respect and self-worth, along with respect and esteem from peers. The desire for recognition, achievement, status, and power fits in this category. Money and financial rewards may also help satisfy esteem needs, because they provide signals of people's "worth" to the organization.

5. Self-actualization needs represent the desire to realize personal potential, self-fulfillment, seeking personal growth and peak experiences.

According to Maslow's theory, each need is proponent over all higher-level needs until it has been satisfied. A proponent need is one that predominates over other needs (Hitt et al., 2011).

\section{Two-Factor Theory}

The two-factor theory is based on the work of Frederick Herzberg. It has some similarities to the other need theories, but it focuses more on the rewards or outcomes of performance that satisfy individuals' needs. The twofactor theory emphasizes two sets of rewards or outcomes - those related to job satisfaction and those related to job dissatisfaction. This theory suggests that satisfaction and dissatisfaction are not opposite ends of the same continuum but are independent states. In other words, the opposite of high job satisfaction is not high job dissatisfaction; rather, it is low job satisfaction. Likewise, the opposite of high dissatisfaction is low dissatisfaction. It follows that the job factors leading to satisfaction are different from those leading to dissatisfaction, and vice versa. The factors related to job satisfaction have been called satisfiers, or motivators. These are factors that, when increased, will lead to greater levels of satisfaction. They include: achievement, recognition, responsibility, opportunity for advancement or promotion, challenging work, potential for personal growth. The factors related to dissatisfaction have been called dissatisfies, or hygienes. When these factors are deficient, dissatisfaction will increase. However, providing greater amounts of these factors will not lead to satisfaction-only to less dissatisfaction. Hygiene factors include: pay, 
technical supervision, working conditions, company policies, administration and procedures, interpersonal relationships with peers, supervisors and subordinates, status, security (Hitt et al., 2011).

Process theories of motivation generally focus on the cognitive processes in which people engage to influence the direction, intensity and persistence of their behavior. Three important process theories are: Expectancy theory, Equity theory and Goal-setting theory.

\section{Expectancy theory}

Vroom in his Expectancy theory suggests that the motivation to work depends on the relationships between the three expectancy factors:

- $\quad$ Expectancy - a person's belief that working hard will result in a desired level of task performance being achieved (this is sometimes called effort-performance expectancy).

- Instrumentality - a person's belief that successful performance will be followed by rewards and other potential outcomes (this is sometimes called performance-outcome expectancy).

- Valence - the value a person assigns to the possible rewards and other work-related outcomes.

In the expectancy theory, motivation (M), expectancy (E), instrumentality (I), and valence (V) are related to one another in a multiplicative fashion: $\mathrm{M}=\mathrm{E} \times \mathrm{I} x \mathrm{~V}$. Mathematically speaking, a zero at any location on the right side of the equation (that is, for $\mathrm{E}$, I, or V) will result in zero motivation. This multiplier effect has important managerial implications. The advice is to: (1) maximize expectancy - people must believe that if they try, they can perform; (2) maximize instrumentality people must perceive that high performance accomplishments will be followed by desired work outcomes; (3) maximize valence - people must value the outcomes.

\section{Equity Theory}

In 1963, John Stacey Adams introduced the idea that fairness and equity are key components of a motivated individual. Equity theory is based in the idea that individuals are motivated by fairness, and if they identify inequities in the input or output ratios of themselves and their referent group, they will seek to adjust their input to reach their perceived equity. Adams suggested that the higher an individual's perception of equity, the more motivated they will be and vice versa: if someone perceives an unfair environment, they will be de-motivated.

These equity comparisons are especially common whenever managers allocate things like pay raises, vacation schedules, preferred job assignments, work privileges, and office space. The equity comparisons may 
be with co-workers in the group, workers elsewhere in the organization, and even persons employed by other organizations.

An individual who perceives that she or he is being treated unfairly in comparison to others will be motivated to act in ways that reduce the perceived inequity. And when perceived negative inequity exists, Adams predicts that people will try to deal with it by: changing their work inputs by putting less effort into their jobs; changing the rewards received by asking for better treatment; changing the comparison points to make things seem better; changing the situation by leaving the job (Schermerhorn et al., 2012).

\section{Goal-Setting Theory}

The goal-setting theory described by Edwin Locke focuses on the motivational properties of task goals. The basic premise is that task goals can be highly motivating if they are properly set and if they are well managed. This theory states that specific and challenging goals along with appropriate feedback contribute to higher and better task performance.

The important features of goal-setting theory are: Goals give direction to people in their work. Goals clarify the performance expectations in supervisory relationships, between co-workers, and across subunits in an organization. Goals establish a frame of reference for task feedback. The willingness to work towards attainment of goal is main source of job motivation. Clear and specific goals are greater motivating factors than general and imprecise goals and they lead to greater output and better performance. Goals should be realistic and challenging. This gives an individual a feeling of pride and triumph when he attains them, and sets him up for attainment of next goal. The more challenging the goal, the greater the reward is generally and the greater the passion for achieving it is. Better and appropriate feedback of results directs the employee behavior and contributes to higher performance than absence of feedback. Participation of setting goal makes goal more acceptable and leads to more involvement. And finally, goals also provide a foundation for behavioral self-management.

\section{Motivation of older adults}

The work motives of older workers fit into explained motivation theories. Although there are many stereotypes about older employees, especially in direction of their ability, performance, motivation and change acceptance, the fact is that there is an increase in the percentage of employees over 50 years in many companies. This fact demands, in the context of work motivation, that these employees should be observed equally and fairly compared to younger employees, that is, aligned with the equity theory of motivation. 
Lord (2004) found out that the primary reasons for older workers to remain active in the workforce are that they enjoy working, derive satisfaction from using their skills, gain a sense of accomplishment from the job they perform, and enjoy the chance to be creative that is align with Herzberg two factor theory. Higgs et al. (2003) highlight that older employees work because of financial reasons, the work itself, or their traditional work ethic. Leviatan (1992) pointed out that older workers prefer jobs that satisfy higher order needs (Maslow's theory). Lord (2002) found out that older engineers with insufficient income to retire, work to satisfy the first and second level needs in terms of Maslow's hierarchy, which in Herzberg two factor theory represent hygiene factors; whereas older engineers with sufficient income to retire are primarily motivated by needs that correspond to the third and fourth levels of Maslow's hierarchy, and in Herzberg two factor theory represent motivators. Similarly, Ng and Feldman (2010) in their meta-analysis found out a significant correlation of age with intrinsic work motivation (motivators in Herzberg's theory).

Regarding the goal setting theory that suppose that goal specificity, goal difficulty, and goal commitment enhance task performance, it should be pointed out that older workers' motivation decreases when they compare their performance to the performance of their younger colleagues (Warr, 2001). But, their performance and their goals should be observed differently compared to younger employees. Ng and Feldmans (2008) found out that older workers show high performance on organizational citizenship behaviors, suggesting that older workers should be engaged in discretionary behaviors to compensate for any losses in technical core performance. People adapt to ageing by seeking to maximize social and emotional gains. Older people care more about experiencing meaningful social ties and invest more in the quality of social relationships. They experience a greater need for passing on knowledge and skills to younger workers through training and supervising. To summarize, older adults tend to prioritize emotion-regulation goals. Social activities and a sense of belonging in the social environment become a greater source of their satisfaction (Stamov-Robnagel and Biemann, 2012). To enhance work motivation among older workers, Kanfer and Ackerman (2004) proposed that performance goals for older workers could include responsibility for others, job dedication, training effectiveness, problem-solving, and project management. They further proposed that performance rewards for older workers could include opportunities for positive affective events and/or strengthened sense of identity. Specific motivators may be performance goals and rewards such as autonomy, participation in training, transfer of their competence, and taking up relevant roles in work teams (Kooij et al., 2008). And finally, regarding the expectancy theory, older employees will invest effort if they perceive that 
this will lead to performance. Also, they tend to believe that the achieved performance will be followed by satisfactory rewards. So, this theory should be observed in the context of motivation factors proposed by Maslow's theory and Herzberg theory, as well as propositions of the goal setting theory.

\section{Methodology}

This paper is based on the large empirical investigation conducted within the project InCounceling 50+ co-funded by the European Commission through the Erasmus+ Programme. The research in Croatia was conducted in 2017 in 6 Croatian companies. The research instrument was a specially designed questionnaire with 30 questions divided in four parts. The questions relevant for this paper were about employees' general characteristics, employees' competencies and motivational factors. These questions were completed by 141 employees. The collected data was analyzed by the usual statistics methods supported by SPSS program.

\section{Research Results}

The presentation of the research results will start with the respondents' characteristics. The respondents were employees older than 50 years. So, the average age of respondents is 55 years. Additionally, Table 1 represents distribution of respondents by gender, education level and position in the company.

Table 1 Distribution of respondents by gender, education level and job position

\begin{tabular}{|c|c|c|c|c|}
\hline & & Frequency & Percent & $\begin{array}{c}\text { Cumulative } \\
\text { Percent } \\
\end{array}$ \\
\hline \multirow{5}{*}{ Gender } & Male & 69 & 49.6 & 49.6 \\
\hline & Female & 70 & 50.4 & 100.0 \\
\hline & Total of respondents & 139 & 100 & - \\
\hline & Missing & 2 & 1.4 & - \\
\hline & Total & 141 & - & - \\
\hline \multirow{4}{*}{$\begin{array}{l}\text { Level of } \\
\text { education }\end{array}$} & Basic education & 6 & 4.3 & 4.3 \\
\hline & $\begin{array}{c}\text { Secondary education/Vocational } \\
\text { education }\end{array}$ & 74 & 52.5 & 56.7 \\
\hline & Higher education (University education) & 61 & 43.2 & 100.0 \\
\hline & Total of respondents & 141 & 100 & - \\
\hline \multirow{8}{*}{ Position } & Un/Semiskilled employees & 8 & 5.9 & 5.9 \\
\hline & Skilled employees & 41 & 30.4 & 36.3 \\
\hline & Officials & 20 & 14.8 & 51.1 \\
\hline & Experts & 27 & 20.0 & 71.1 \\
\hline & Managers & 39 & 28.9 & 100.0 \\
\hline & Total or respondents & 135 & 100 & - \\
\hline & Missing & 6 & 4.3 & - \\
\hline & Total & 141 & - & - \\
\hline
\end{tabular}


Regarding the gender, in Table 1, it can be perceived that $50.4 \%$ of respondents are women, while $49.6 \%$ are men. The majority of respondents $(52.5 \%)$ have secondary or vocational education, $43.2 \%$ is highly educated, and $4.3 \%$ of them have just basic education. Concerning the position in the company, the majority of respondents are skilled employees, $30.4 \%$ of them. Managers are $28.9 \%, 20 \%$ are experts, $14.8 \%$ are officials and $5.9 \%$ are un/semiskilled employees.

Since employees' competencies are foundation for the employees' motivation, the empirical research of this paper was focused on the employees' opinion about their competencies in comparison with the job requirements. Namely, if employees do not have sufficiently developed competencies, the process of motivation is restricted or even obstructed. Table 2 represents the opinion of respondents about their competencies.

Table 2 Respondents' opinion about their competencies in comparison with the job requirements

\begin{tabular}{|c|c|c|c|}
\hline & Frequency & Percentage & $\begin{array}{c}\text { Cumulative } \\
\text { percentage }\end{array}$ \\
\hline $\begin{array}{c}\text { My competences are higher than the } \\
\text { requirements of my job }\end{array}$ & 33 & 23.9 & 23.9 \\
\hline $\begin{array}{c}\text { I have sufficient competences to } \\
\text { perform work at the position held }\end{array}$ & 96 & 69.6 & 93.5 \\
\hline $\begin{array}{c}\text { I do not have sufficient competences to } \\
\text { work in the position held }\end{array}$ & 7 & 5.1 & 98.6 \\
\hline I have no opinion & 2 & 1.4 & 100 \\
\hline Total of respondents & 138 & 100 & - \\
\hline Missing & 3 & 2.1 & - \\
\hline Total & 141 & - & - \\
\hline
\end{tabular}

The great majority of employees $(93.5 \%)$ considered that they had sufficient or even higher competencies required for their job position. Only $5.1 \%$ of employees thought that they did not have sufficient competencies to work in the position that they held. Therefore, it could be concluded that prerequisites for motivation process were satisfied.

Table 3 represents which motivational factors are important for employees $50+$.

Table 3 Motivational factors for employees 50+

\begin{tabular}{|c|c|c|c|}
\hline & N & Mean & $\begin{array}{c}\text { Std. } \\
\text { Deviation }\end{array}$ \\
\hline Financial factors & 141 & 3.89 & .942 \\
\hline Safety and stability of employment & 140 & 4.13 & .794 \\
\hline Career development & 137 & 3.28 & 1.064 \\
\hline Self-development & 139 & 3.65 & 1.041 \\
\hline Good atmosphere at work & 141 & 4.33 & .761 \\
\hline Respect and recognition & 141 & 4.25 & .911 \\
\hline
\end{tabular}


Respondents were asked to evaluate the motivational potential of 6 motivational factors using Likert's scale from 1 to 5 , where 1 represents "not motivating", 2 represents "hardly motivating", 3 represents "undecided", 4 represents "motivating" and 5 represents "very motivating". From Table 3, it could be noticed that good atmosphere at work is the most important motivational factor for employees 50+ with the highest mean value of 4.33. Very close to good atmosphere at work is the respect and recognition (mean value 4.25); followed by safety and stability of employment (mean value 4.13). Career development is the least important motivational factor for employees $50+$, with the mean value of 3.28 , which is logical because these employees, during their careerexperienced different promotions and development. Now, they are preparing for the process of transition to retirement, they try to slow down, and they are not so preoccupied with their career development. So, in that context, it is understandable that they prefer a good atmosphere at work and stable employment.

This paper has also examined the existence of differences in motivational factors in relation to employees' gender, level of education and job position. Table 4 represents the result of Mann-Whitney test of differences in motivational factors regarding employees' gender.

Table 4 Mann-Whitney test of differences in motivational factors regarding employees' gender

\begin{tabular}{|c|c|c|c|c|c|c|}
\hline & $\begin{array}{c}\text { Motivation- } \\
\text { Financial } \\
\text { factors }\end{array}$ & $\begin{array}{c}\text { Motivation- } \\
\text { Safety and } \\
\text { stability of } \\
\text { employment }\end{array}$ & $\begin{array}{c}\text { Motivation- } \\
\text { Career } \\
\text { development }\end{array}$ & $\begin{array}{c}\text { Motivation- } \\
\text { Self- } \\
\text { development }\end{array}$ & $\begin{array}{c}\text { Motivation- } \\
\text { Good } \\
\text { atmosphere } \\
\text { at work }\end{array}$ & $\begin{array}{c}\text { Motivation- } \\
\text { Respect and } \\
\text { recognition }\end{array}$ \\
\hline $\begin{array}{c}\text { Mann- } \\
\text { Whitney U }\end{array}$ & 2340.000 & 2331.000 & 2243.000 & 2320.500 & 2206.000 & 2162.000 \\
\hline $\begin{array}{c}\text { Wilcoxon } \\
\text { W }\end{array}$ & 4755.000 & 4746.000 & 4589.000 & 4735.500 & 4621.000 & 4577.000 \\
\hline Z & -.343 & -.233 & -.162 & -.118 & -.982 & -1.169 \\
\hline $\begin{array}{c}\text { Asymp. Sig. } \\
\text { (2-tailed) }\end{array}$ & .731 & .816 & .871 & .906 & .326 & .242 \\
\hline
\end{tabular}

a. Grouping Variable: Gender

Based on the data from Table 4, given that $\alpha>0.05$, regarding all observed motivational factors, it could be concluded that, there is no statistically significant difference in motivational factors of employees $50+$ regarding their gender.

Table 5 represents the result of Kruskal-Wallis test of differences in motivational factors regarding employees' level of education. 
Table 5 Kruskal-Wallis test of differences in motivational factors regarding employees' level of education

\begin{tabular}{|c|c|c|c|c|c|c|}
\hline & $\begin{array}{c}\text { Motivation- } \\
\text { Financial } \\
\text { factors }\end{array}$ & $\begin{array}{c}\text { Motivation- } \\
\text { Safety and } \\
\text { stability of } \\
\text { employment }\end{array}$ & $\begin{array}{c}\text { Motivation- } \\
\text { Career } \\
\text { development }\end{array}$ & $\begin{array}{c}\text { Motivation- } \\
\text { Self } \\
\text { development }\end{array}$ & $\begin{array}{c}\text { Motivation- } \\
\text { Good } \\
\text { atmosphere } \\
\text { at work }\end{array}$ & $\begin{array}{c}\text { Motivation- } \\
\text { Respect and } \\
\text { recognition }\end{array}$ \\
\hline Chi-Square & 2.996 & 1.809 & 2.973 & 2.291 & .502 & .770 \\
\hline df & 2 & 2 & 2 & 2 & 2 & 2 \\
\hline $\begin{array}{c}\text { Asymp. } \\
\text { Sig. }\end{array}$ & .224 & .405 & .226 & .318 & .778 & .681 \\
\hline \multicolumn{7}{|c|}{ a. Kruskal Wallis Test } \\
\hline \multicolumn{7}{|c|}{ Grouping Variable: Level of education } \\
\hline
\end{tabular}

From Table 5, it could be observed, that there is no statistically significant difference in motivational factors of employees 50+ regarding their level of education, since $\alpha>0.05$ in terms of all observed motivational factors.

Table 6 represents the result of Kruskal-Wallis test of differences in motivational factors regarding employees' level of education.

Table 6 Kruskal-Wallis test of differences in motivational factors regarding employees' position

\begin{tabular}{|c|c|c|c|c|c|c|}
\hline & $\begin{array}{c}\text { Motivation- } \\
\text { Financial } \\
\text { factors }\end{array}$ & $\begin{array}{c}\text { Motivation- } \\
\text { Safety and } \\
\text { stability of } \\
\text { employment }\end{array}$ & $\begin{array}{c}\text { Motivation- } \\
\text { Career } \\
\text { development }\end{array}$ & $\begin{array}{c}\text { Motivation- } \\
\text { Self } \\
\text { development }\end{array}$ & $\begin{array}{c}\text { Motivation- } \\
\text { Good } \\
\text { atmosphere } \\
\text { at work }\end{array}$ & $\begin{array}{c}\text { Motivation- } \\
\text { Respect and } \\
\text { recognition }\end{array}$ \\
\hline Chi-Square & 1.770 & .976 & 3.461 & 1.124 & .179 & .717 \\
\hline $\mathrm{df}$ & 2 & 2 & 2 & 2 & 2 & 2 \\
\hline $\begin{array}{c}\text { Asymp. } \\
\text { Sig. }\end{array}$ & .413 & .614 & .177 & .570 & .914 & .699 \\
\hline \multicolumn{7}{|c|}{ a. Kruskal Wallis Test } \\
\hline \multicolumn{7}{|c|}{ b. Grouping Variable: Position } \\
\hline
\end{tabular}

Kruskal-Wallis test, presented in Table 6, suggests that there is no statistically significant difference in motivational factors of employees $50+$ regarding their job position, since $\alpha>0.05$ in the case of all observed motivational factors.

\section{Conclusion}

Ageing of population, especially in highly developed countries brings into contemporary companies increased percentage of employees older than 50. Therefore, human resource management in these companies should focus particularly in the process of motivation to the age cohort of the employees $50+$. Since, there is a lack of empirical research about this issue, this paper 
gives makes a contribution in this context by exploring the motivational factors relevant for employees $50+$.

The research results showed that employees 50+ consider that they have sufficient or even higher competencies required for their job position. By this, the preconditions for their motivation are satisfied. Regarding motivational factors, good atmosphere at work is the most important motivational factor for employees 50+, followed by the respect and recognition and safety and stability of the employment. Career development is the least important motivational factor for employees 50+. Additionally, research results showed that there are no statistically significant differences in motivational factors of employees 50+ regarding their gender, educational level and job position.

These results support Maslow's and Herzberg's motivation theories, as well as the research of Levitan (1992), Lord (2004) and Ng and Feldman (2010), by suggesting that companies in the motivation process of employees $50+$ should be primarily focused on higher order needs and hygiene factors of motivation.

Additionally, this research showed that safety and stability of employment is also an important motivational factor to employees 50+. So, in the process of motivation, companies should connect these findings by providing employees 50+ stable employment, engaging them in different social interactions which are so important to them. In this context, in order to be motivated, the older employees should be involved in the process of employees' orientation and mentoring. This is in line with previous studies following by Kanfer and Ackerman (2004), Ng and Feldmans (2008), Kooij et al. (2008) and Stamov-Robnagel and Biemann, (2012).

Related to goal setting theory, the goals of employees 50+ should be knowledge sharing, transfer of competence, coaching, mentoring and similar behaviors. Those elements are not exactly measurable performances, but they are behaviors with significant positive influence on overall organizational performance. So, the companies should utilize the experience and motivation of employees 50+ in direction of achieving the positive outcomes of this kind of behaviors.

Those conclusions should be taken with some reservations because of the research limitations. The first limitation is the small sample. Only 6 Croatian companies participated in the research which significantly limits the generalization of the conclusions. So, further research should expand the research sample. Additionally, the analysis of motivation is very narrow, so suggestion for future research could be to apply a broader analysis of motivational factors and other elements related to the work motivation, such as performance, job satisfaction, organizational commitment, etc. And finally, it could be interesting and meaningful to compare the employees 50+ 
to other employees, in the context of their work motivation, in order to develop efficient motivation strategies for each group.

\section{References:}

1. Christian Stamov-Roßnagel, Torsten Biemann, (2012) "Ageing and work motivation: a task-level perspective", Journal of Managerial Psychology, Vol. 27 Issue: 5, pp.459-478,

2. Higgs, P., Mein, G., Ferrie, J., Hyde, M. and Nazroo, J. (2003): Pathways to early retirement: structure and agency in decisionmaking among British civil servants. Ageing \& Society, Vol. 23, pp. 761-78.

3. Hitt, M. A., Miller, C. C. and Colella, A. (2011): Organizational Behaviour, International Student Version, 3th ed., John Wiley \& Sons, Inc, Asia.

4. Kanfer, R. and Ackerman, P.L. (2004): Aging, adult development and work motivation. Academy of Management Review, vol. 29, no. 3, pp. 440-58.

5. Kooij, D., de Lange, A., Jansen, P., Dikkers, J. (2008): Older workers' motivation to continue to work: five meanings of age. Journal of Managerial Psychology, Vol. 23, No.4, pp. 364-394.

6. Leviatan, U. (1992): Determinants of work motivation and work satisfaction among kibbutz aged workers. Canadian Journal of Community Mental Health, vol. 11, pp. 49-64.

7. Lord, R.L. (2002): Traditional motivation theories and older engineers. Engineering Management Journal, Vol. 14, No. 3, pp. 3-7.

8. Lord, R.L. (2004): Empirical evaluation of classical behavioral theories with respect to the motivation of older knowledge workers, dissertation, University of Alabama, Tuscaloosa, AL.

9. Ng, T.W.H. and Feldman, D.C. (2010): The relationship of age with job attitudes: a meta-analysis, Personnel Psychology, vol. 63, no. 3, pp. 677-718.

10. Schermerhorn, J.R., Osborn, R. N., Uhl-Bien, M., Hunt, J. G. (2012): Organizational Behavior $12^{\text {th }}$ ed., John Wiley\&Sons, New York., pp. 292.

11. Warr, P. (2001): Age and work behaviour: physical attributes cognitive abilities, knowledge, personality traits, and motives. International Review of Industrial and Organizational Psychology, vol. 16, pp. 1-36. 